\title{
Simulasi Seleksi Pemain Futsal Porprov Bali Menggunakan Sistem Pendukung Keputusan Untuk Meningkatkan Kesiapan Atlet (Studi Kasus : Fakultas Olahraga dan Kesehatan, Undiksha)
}

\author{
Ni Putu Dwi Sucita Dartini ${ }^{1)}$, Agus Aan Jiwa Permana ${ }^{2)}$, Kadek Wirahyuni ${ }^{3)}$ \\ Prodi Pendidikan Jasmani Kesehatan dan Rekreasi, Undiksha, Singaraja, Bali ${ }^{1}$ \\ Prodi Manajemen Informatika, Undiksha, Singaraja, Bali ${ }^{2)}$ \\ Prodi Pendidikan Bahasa Indonesia, Undiksha, Singaraja, Bali ${ }^{3)}$ \\ dwisucita@gmail.com ${ }^{1)}$ agus.aan@undiksha.ac.id ${ }^{2)}$ wirahyuni27@gmail.com ${ }^{3)}$
}

\begin{abstract}
Based on the experience of the writers who participated in the Porprov Bali committee, observations in the Futsal athlete's assessment involved more subjectivity. Subjective decisions can be detrimental to many parties, especially among Futsal athletes themselves. The sports branch is highly emphasized on the value of sportsmanship, so it is necessary to involve a tool to help solve the problem. Decision support systems (SPK) can be used as tools that aim to reduce the level of subjectivity in the assessment process for semi-structured problems. SPK is used as a simulation that will be used for students majoring in physical education at the Sports and Health Faculty, Undiksha to find out whether they are eligible to pass the Porprov selection. With SPK it will produce more objective decisions in semi-structured situations such as determining futsal athletes that can be passed to Porprov because the results of decisions issued minimize the use of intuition.
\end{abstract}

Keywords: Selection of Futsal, Porprov Bali athletes, SPK, Semiterstructure Decisions

\begin{abstract}
ABSTRAK
Berdasarkan pengalaman penulis yang ikut dalam kepanitiaan Porprov Bali secara observasi dalam penilaian atlet Futsal lebih banyak melibatkan faktor subyektifitas. Keputusan yang bersifat subyektif dapat merugikan banyak pihak, khususnya di kalangan atlet Futsal itu sendiri. Cabang olahraga sangat ditekankan nilai sportifitas sehingga perlu dilibatkan sebuah tools (alat bantu) untuk membantu memecahkan masalah tersebut. Sistem pendukung keputusan (SPK) dapat digunakan sebagai tools yang vertujuan untuk menurunkan tingkat subyektifitas dalam proses penilaian untuk permasalahan semiterstruktur. SPK digunakan sebagai simulasi yang akan digunakan untuk mahasiswa jurusan pendidikan jasmani pada Fakultas Olahraga dan Kesehatan, Undiksha untuk mengetahui apakah mereka layak untuk lolos dalam seleksi Porprov. Dengan SPK akan menghasilkan keputusan yang lebih obyektif dalam situasi semiterstuktur seperti dalam menentukan atlet futsal yang dapat diloloskan ke Porprov karena hasil keputusan yang dikeluarkan memperkecil penggunaan intuisi..
\end{abstract}

Kata Kunci : Seleksi atlet Futsal, Porprov Bali, SPK, Keputusan Semiterstruktur 


\section{PENDAHULUAN}

Seiring dengan perkembangan teknologi komputer yang merambah ke segala bidang akan sangat membantu dalam mendukung pegolahan data. Data diolah untuk menghasilkan sebuah keputusan yang nantinya dapat digunakan dalam menentukan keputusan yang tepat. Dalam perkembangan masyarakat ekonomi asean (MEA) sangat perlu untuk mendalami penggunaan media informasi untuk memperoleh perbandingan informasi dalam menyelesaikan masalah tertentu.

Pada bidang komputer misalkan, di luar negeri wasit sudah melibatkan kamera untuk mendeteksi apabila terjadi pelanggaran dalam permainan sepak bola. Kemudian dalam merekrut pemain saat ini sudah ada menggunakan media sosial seperti LinkedIn. Sebuah klub sepak bola profesional Slovenia, Domzale, mencoba cara baru dalam hal menggaet pemain anyar. Manajemen Domzale menggunakan media sosial LinkedIn untuk urusan merekrut pemain baru (Wicaksono, 2016).

Berdasarkan pengalaman penulis yang ikut dalam kepanitiaan Porprov Bali 2015 secara observasi dalam penilaian atlet lebih banyak melibatkan faktor subyektifitas. Dengan keadaan seperti itu, perlu kiranya dikembangkan sebuah aplikasi untuk membantu dalam proses seleksi atlet yaitu berupa aplikasi sistem pendukung keputusan. Berdasarkan hasil wawancara dengan I Nyoman Wahyu Esa Wijaya, S.Pd.,M.Pd selaku panitia yang bertugas di bidang Futsal, beliau mengatakan dalam proses seleksi hanya menggunakan metode observasi dan keputusan yang diambil lebih mengarah ke intuisi tanpa ada tools yang dilibatkan untuk mendukung dalam proses pengambilan keputusan.

Sistem pendukung keputusan (SPK) dapat digunakan sebagai tools (alat bantu) untuk menurunkan tingkat subyektifitas dalam proses penilaian untuk permasalahan semiterstruktur. Pemecahan masalah semiterstruktur merupakan kombinasi antara prosedur solusi solusi standar dan penilaian manusia (Permana, 2016 ). Selain itu, SPK juga dapat digunakan sebagai simulasi untuk mahasiswa pada Fakultas Olahraga dan Kesehatan di Undiksha untuk mengetahui berapa skor mereka sehingga mereka layak untuk diloloskan dalam seleksi Porprov di tahun mendatang. Adapun kelebihan dari penggunaan aplikasi yang akan dikembangkan ini adalah dapat menghasilkan alternatif keputusan berdasarkan rangking dari kriteria yang akan digunakan.

Walaupun perangkingan ditentukan sistem, namun dalam mengambil keputusan masih dapat memungkin bagi pengguna untuk menarik kesimpulan sesuai dengan analisisnya masing-masing sehingga keputusan tidak kaku dan dapat disesuaikan dengan keputuhan pengguna. Hal inilah yang menjadi kelebihan dari SPK itu sendiri. Keputusan yang diambil dengan bantuan SPK, dapat menghasilkan keputusan yang lebih obyektif dalam situasi semiterstuktur seperti dalam menentukan atlet futsal yang dapat diloloskan ke Porprov.

Proses evaluasi adalah proses untuk memberikan informasi tentang sejauh mana kegiatan telah dicapai dengan melihat perbedaan hasil di lapangan dengan target yang sudah terstandar. Berdasarkan wawancara di lapangan, proses penilaian hanya berbasis observasi dimana dalam mengambil keputusan akan melibatkan intuisi. Sistem pendukung keputusan dapat digunakan sebagai solusi untuk membantu permasalahan semiterstruktur seperti Gambar 1.

Sistem menggunakan metode Simple Additive Weighting (SAW). Konsep dasar metode SAW adalah mencari penjumlahan terbobot dari rating kinerja pada setiap alternatif pada semua atribut. Metode SAW membutuhkan proses normalisasi matriks keputusan (X) ke suatu skala yang dapat diperbandingkan dengan semua rating alternatif yang ada. 


\section{METODOLOGI PENELITIAN}

\section{Olahraga Futsal}

Rifanalfaizin (2015) mengatakan futsal pertama kali dimainkan di Montevideo, Uruguay pada tahun 1930,oleh Juan Carlos Ceriani. Pertandingan internasional pertama diadakan padatahun1965, Paraguay menjuarai Piala Amerika Selatan pertama. Enam perebutan Piala Amerika Selatan berikutnya diselenggarakan hingga tahun 1979, dan semua gelaran juaranya Brasil. Brasil meneruskan dominasinya dengan meraih Piala Pan Amerika pertama tahun 1980 dan memenangkannya lagi pada perebutan berikutnya tahun pd 1984. Kejuaraan Dunia Futsal pertama diadakan atas bantuan FIFUSA (sebelum anggotaanggotanya bergabung dengan FIFA pada tahun 1989) di Sao Paulo, Brasil, tahun 1982, berakhir dengan Brasil di posisi pertama. Brasil mengulangi kemenangannya di Kejuaraan Dunia kedua tahun 1985 di Spanyol, tetapi menderita kekalahan dari Paraguay dalam Kejuaraan Dunia ketiga tahun 1988 di Australia. Pertandingan futsal internasional pertama diadakan di AS pada Desember 1985, di Universitas Negeri Sonoma di Rohnert Park, California.

Futsal memiliki peraturan tersendiri dibandingkan sepakbola, semua peraturan permainan futsal sudah disepakati dan diatur tersendiri oleh FIFA. Tetapi, dengan menghormati kesepakatan dari asosiasiasosiasi terkait dan yang telah mempersiapkan prinsip-prinsip dari peraturan-peraturan ini, peraturan permainan futsal dapat diubah penerapannya untuk disesuaikan dengan perintah-perintah pemula khususnya yang berusia di bawah 16 tahun, wanita atau untuk pemain yang sudah cukup berumur (melebihi 35 tahun).

\section{Pekan Olahraga Provinsi}

Sejarah PON sendiri berawal setelah proklamasi kemerdekaan yaitu dimulai sekitar tahun 1946. Setelah dibentuk pada tahun 1946, Persatuan Olahraga Republik Indonesia (PORI) yang dibantu oleh Komite
Olimpiade Republik Indonesia (KORI) [yang saat ini keduanya telah dilebur menjadi KONI (Komite Olahraga Nasional Indonesia)] mempersiapkan para atlet Indonesia untuk mengikuti Olimpiade Musim Panas XIV di London pada tahun 1948. Usaha Indonesia untuk mengikuti olimpiade pada saat itu menemui banyak kendala. PORI sebagai badan olahraga resmi di Indonesia pada saat itu belum diakui dan menjadi anggota resmi Internasional Olympic Committee (IOC), sehingga para atlet yang hendak dikirim tidak dapat diterima dan berpartisipasi dalam peristiwa olahraga sedunia tersebut (Anonim, 2016).

Kota Solo sebagai kota penyelenggara Pekan Olahraga Nasional pertama kalinya pada tanggal 9 sampai dengan 12 September tahun 1948 silam. Selain itu Sejarah PON untuk pertama kalinya juga membawa misi untuk menunjukkan kepada dunia luar bahwa bangsa Indonesia dalam keadaan daerahnya dipersempit akibat Perjanjian Renville, masih dapat membuktikan sanggup mengadakan acara olahraga dengan skala nasional. Kemudian cabang KONI di masing-masing provinsi menyelenggarakan pekan olahraga provinsi (Porprov) dengan tujuan menjaring putrai-putri terbaik daerah untuk mewakili daerahnya di ajang PON.

\section{Proses Pengambilan Data}

Proses pengambilan data pada penelitian ini adalah dengan memberikan angket kepada pakar untuk mengisi skor terhadap semua peserta yang mengikuti seleksi. Adapun variabel yang terdapat dalam angket seperti Tabel 1

Tabel 1. Kriteria Pemain Futsal

\begin{tabular}{|r|l|l|}
\hline No & $\begin{array}{l}\text { Kriteria Pemain } \\
\text { Futsal }\end{array}$ & Posisi \\
\hline 1 & $\begin{array}{l}\text { Mempunyai teknik } \\
\text { menangkap bola yang } \\
\text { baik }\end{array}$ & $\begin{array}{l}\text { Kiper/Penjaga } \\
\text { Gawang }\end{array}$ \\
\hline \hline 2 & $\begin{array}{l}\text { Mempunyai teknik } \\
\text { mem-block/menepis } \\
\text { bola yang baik }\end{array}$ & \\
\hline 3 & $\begin{array}{l}\text { Berani dan cepat } \\
\text { mengambil keputusan }\end{array}$ & \\
\hline
\end{tabular}




\begin{tabular}{|r|l|l|}
\hline $\mathbf{4}$ & $\begin{array}{l}\text { Mampu membaca } \\
\text { permainan lawan } \\
\text { dengan baiki }\end{array}$ & $\begin{array}{l}\text { Anchor } \\
\text { (Pemain } \\
\text { Jangkar) }\end{array}$ \\
\hline $\mathbf{5}$ & $\begin{array}{l}\text { Pintar mengatur } \\
\text { jalannya serangan }\end{array}$ & \\
\hline $\mathbf{6}$ & $\begin{array}{l}\text { Memiliki passing dan } \\
\text { shooting yang akurat }\end{array}$ & \\
\hline $\mathbf{7}$ & $\begin{array}{l}\text { Memiliki fisik yang } \\
\text { bagus }\end{array}$ & $\begin{array}{l}\text { Flank (Pemain } \\
\text { Tengah) }\end{array}$ \\
\hline $\mathbf{8}$ & $\begin{array}{l}\text { Memiliki kecepatan } \\
\text { dalan transisi bertahan } \\
\text { dan menyerang }\end{array}$ & \\
\hline $\mathbf{9}$ & $\begin{array}{l}\text { Memiliki pergerakan } \\
\text { yang dapat } \\
\text { membongkar } \\
\text { pertahanan lawan }\end{array}$ & \\
\hline $\mathbf{1 0}$ & $\begin{array}{l}\text { Kuat menguasai dan } \\
\text { melindungi bola }\end{array}$ & Pivot (Striker ) \\
\hline $\mathbf{1 1}$ & $\begin{array}{l}\text { Memiliki insting gol } \\
\text { yang bagus }\end{array}$ \\
\hline $\mathbf{1 2}$ & $\begin{array}{l}\text { Memiliki pergerakan } \\
\text { yang cepat untuk } \\
\text { membuka ruang atau } \\
\text { celah serangan }\end{array}$ \\
\hline
\end{tabular}

Adapun penelitian terkait sebagai referensi pustaka antaran lain Setyawan dan Sutariyani (2013) melakukan penelitian untuk seleksi atlet bulutangkis menggunakan SPK. Kemudian Tahun berikutnya 2014 Harsiti, dkk melakukan penelitian dengan membuat prototype untuk seleksi atlet berprestasi. Nurseta (2014) meneliti tentang Sistem Pendukung Keputusan Pemilihan Starting Eleven Dalam Cabang Olahraga Sepakbola. Tondo (2014) pada tahun yang sama melakukan penelitian seleksi atlet basket. Hoiruddin \& Maulana(2014) melakukan penelitian yang serupa tentang bola, namun di bidang Futsal. Kemudia yang terakhir Utomo dan Kurniawan (2016) melakukan penelitian tentang seleksi atlet sepakbola untuk posisi tertentu.

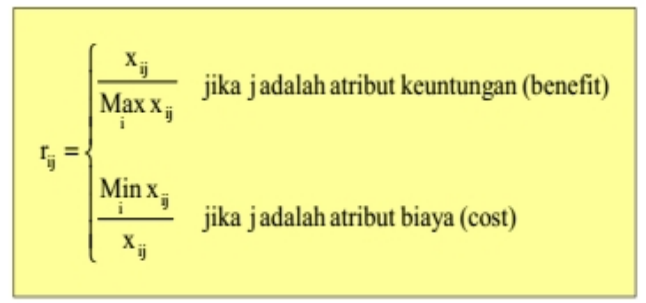

Persamaan 1. Proses Normalisasi Atribut

\section{Simple Additive Weighting (SAW)}

Metode Simple Additive Weighting $(S A W)$ sering juga dikenal istilah metode penjumlahan terbobot.Konsep dasar metode SAW adalah mencari penjumlahan terbobot dari rating kinerja pada setiap alternatif pada semua atribut. Formula untuk melakukan normalisasi tersebut adalah seperti persamaan 1. dengan rij adalah rating kinerja ternormalisasi dari alternatif $A i$ pada atribut $C j ; i=1,2, \ldots$, m dan $j=1,2, \ldots, n$.

$$
\mathrm{V}_{\mathrm{i}}=\sum_{\mathrm{j}=1}^{\mathrm{n}} \mathrm{w}_{\mathrm{j}} \mathrm{r}_{\mathrm{ij}}
$$

Persamaan 2. Proses Pembobotan

Nilai preferensi untuk setiap alternatif $(V i)$ diberikan seperti persamaan 2. Nilai $V i$ yang lebih besar mengindikasikan bahwa alternatif Ai lebih terpilih.

Metode Research and Development (R\&D) Alfindasari (2014) mengatakan bahwa Pada dasarnya penelitian R\&D memiliki karakteristik adanya produk yang dihasilkan dari penelitiannya. Produk yang dihasilkan ini diawali dari analisis kebutuhan dari lokasi penelitian. Secara umum, model R\&D telah dikembangkan oleh beberapa ahli salah satunya model yang dikembangkan oleh Bolt and gall yang mengembangkan model R\&D melalui beberapa tahapan, yakni seperti Gambar 2.

Uji lapangan terbatas (preliminary field test)

Uji lapangan awal produk akan dilakukan di kelas saat mahasiswa mengikuti kuliah Futsal di lapangan kampus. Tahapan dilakukan secara berulang untuk mengetahui kelayakan dari sistem yang dikembangkan.

\section{Uji kelayakan (operational field test)}

Pada tahapan ini melibatkan beberapa pemain Futsal berpengalaman untuk mengetahui efektivitas dan adaptabilitas 
desain melibatkan para calon pemakai produk sehingga sistem yang dikembangkan memang benar-benar efektif untuk menangani masalah yang sedang dihadapi.

\section{Revisi hasil uji kelayakan}

Hasil uji pada tahap sebelumnya dilakukan revisi lagi apabila memang diperlukan untuk menghasilkan produk yang layak. Kelayakan produk dapat diukur dari hasil rekomendasi yang dikelurkan sistem. Hasil rekomendasi dapat digunakan sebagai bahan evaluasi oleh panitia Porprov.

\section{Uji lapangan lebih luas (main field test)}

Pada tahapan ini pengujian sistem dilakukan dengan menggunakan data menggunakan data riil yang melibatkan sejumlah atlet yang terlibat dalam seleksi Futsal Porprov. Semua komponen dalam sistem dilakukan pengecekan untuk memastikan sistem dapat bekerja dengan baik. Hasil keluaran sistem diberikan kepada panitia sebagai bahan pertimbangan untuk seleksi atlet.

\section{Revisi hasil uji lapangan lebih luas}

Apabila terdapat masukkan dari panitia ataupun pengguna lainnya maka akan segera dilakukan revisi untuk menghasilkan sistem yang semakin baik, efektif, dan memiliki hasil layak.

\section{Diseminasi dan sosialisasi produk akhir}

Proses sosialisasi hasil penelitian untuk digunakan khalayak umum, melalui proses publikasi, seminar, dan pelatihan terkait penggunaan sistem.

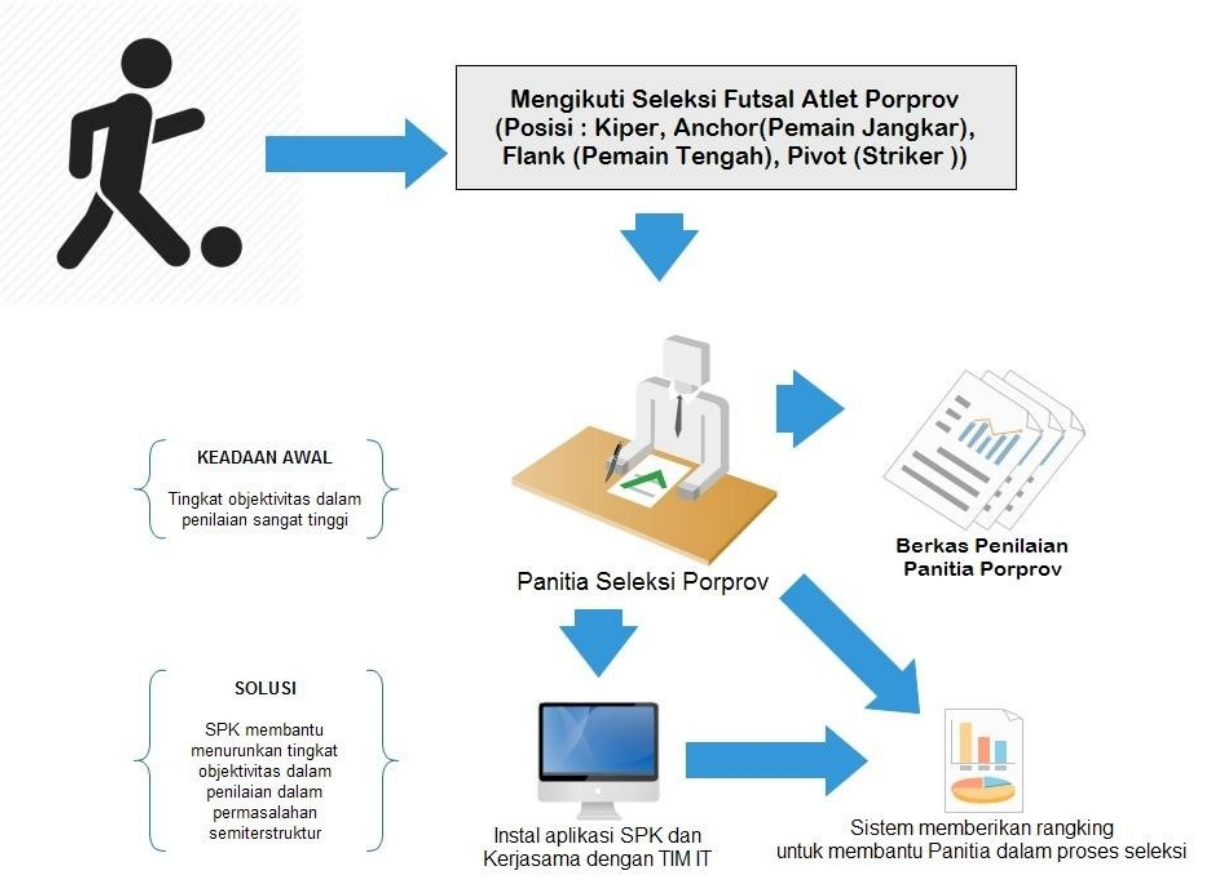

Gambar 1. Rancangan Permasalah dan Solusinya

\section{HASIL DAN PEMBAHASAN}

Data angket dimasukkan ke dalam sistem untuk diproses lebih lanjut menjadi matriks dan kemudian hasilnya di normalisasi seperti Gambar 3. Setelah proses normalisasi maka akan ada perkalian bobot. Hasil akhir dari proses ini adalah berupa alternatif dengan skor bobotnya masing-masing seperti Gambar 4. Skor tersebut yang akan digunakan untuk menentukan keputusan yang tepat untuk diambil. Alternatif mana yang akan diloloskan akan ditentukan oleh para pengambil keputusan (decision maker) dalam hal ini adalah panitia seleksi. Kemudian 
dalam hasil perhitungan untuk mempermudah melakukan analisis juga ditampilkan grafik seperti pada Gambar 5.

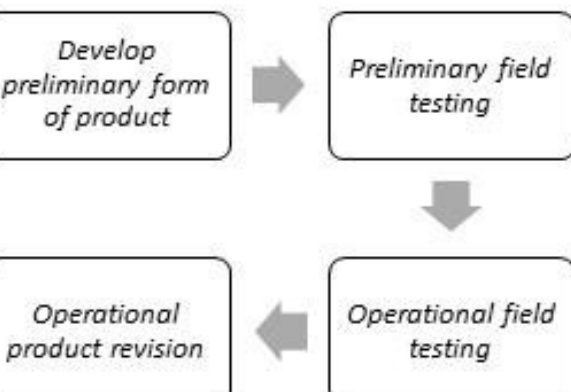

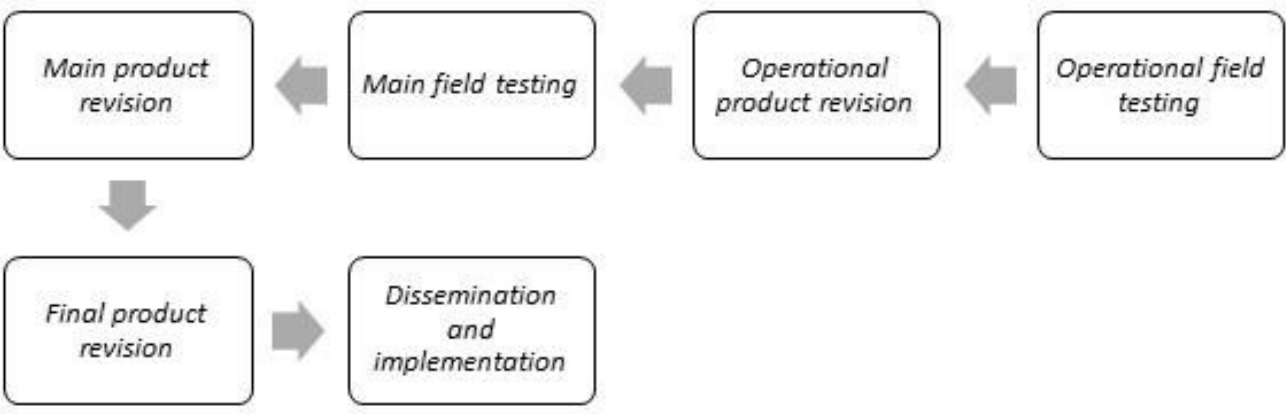

Gambar 2. Tahapan Metode R\&D

Tambah Rangking

Alternatif

Ahmad Baydawi

Kriteria

Mempunyai teknik menangkap bola yang baik (Kiper)

Nilai

Rendah

\section{SIMPAN KEMBAL}

Gambar 3. Proses Penilaian Alternatif

Data Alternatif

\begin{tabular}{|l|l|l|}
\hline \multicolumn{1}{|l|}{ Show 10} & entries & Sesil Alternatif \\
\hline No $\quad$ Ni & Nama Alternatif & 6 \\
\hline 1 & Ahmad Baydawi & 4.999999999999997 \\
\hline 2 & I Putu Adnyana & 4.999999999999997 \\
\hline 3 & Putu Ryan Dharma Putra & 7 \\
\hline 4 & Komang Itfan Tri Eri Eryanto & 4.666666666666667 \\
\hline 5 & Septyan Fernando Pasaribu & Hasil Alternatif \\
\hline No & Nama Alternatif & \\
\hline Showing 1 to 5 of 5 entries & \\
\hline
\end{tabular}


Gambar 4. Hasil Penilaian Akhir dari Alternatif

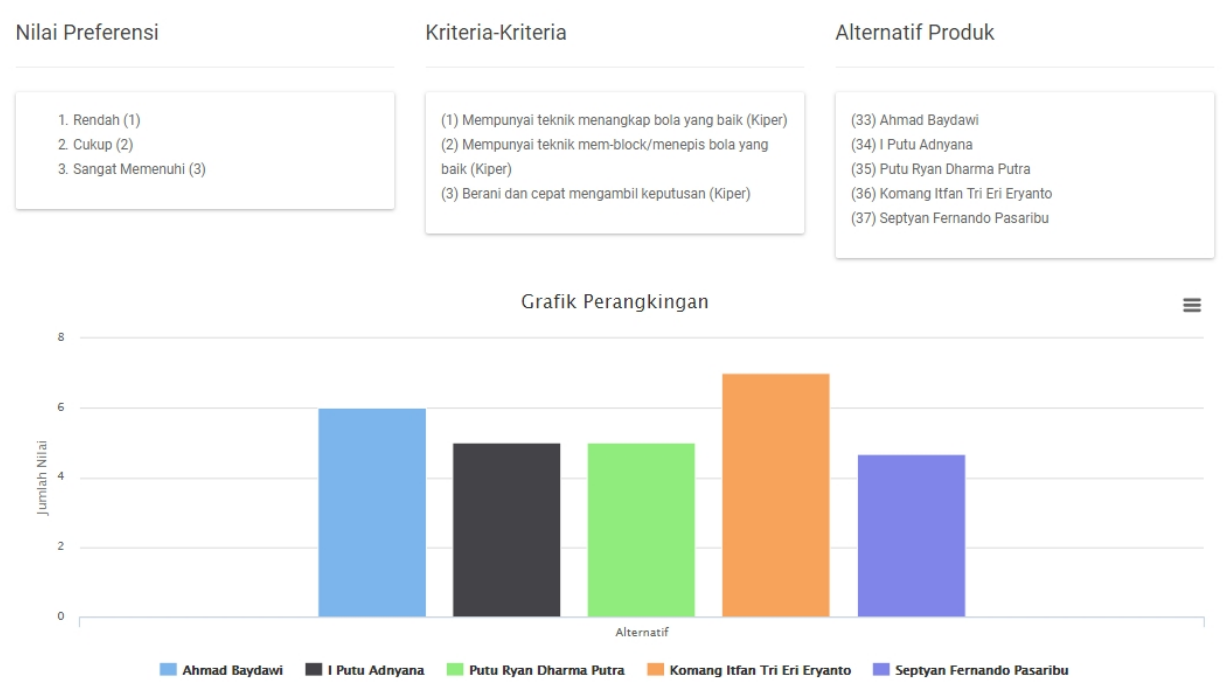

Gambar 5. Grafik Hasil Perangkingan

\section{SIMPULAN}

Seleksi pemain yang lebih obyektif dalam permasalahan semiterstruktur telah berhasil diimplentasikan dengan menggunakan sistem pendukung keputusan berbasis pemodelan Simple Additive Weighting (SAW). Sistem yang ada sudah mampu untuk menangani permasalahan pemilihan pemain Futsal untuk posisi Kiper/Penjaga Gawang, Anchor (Pemain Jangkar), Flank (Pemain Tengah), Pivot (Striker). Sistem sudah berhasil memberikan solusi untuk alternatif pemilihan keputusan pemain serta ditampilkan dalam bentuk angka dan grafik. Walaupun demikian sistem perlu diujikan lebih lanjut untuk penilain yang lebih baik lagi.

\section{DAFTAR PUSTAKA}

[1] Anonim, 2016, Sejarah PON untuk Pertama Kalinya di Indonesia Lengkap Juara Umum Sampai Tahun 2016, http://www.penemuanterbaru.co m/2016/09/sejarah-pon.html, (diakses: 29 Oktober 2016)
[2] Efraim, T., Aronson, J. E., Liang, Ting-Peng, 2005, Sistem

Pendukung Keputusan dan Sistem Cerdas, edisi I, diterjemahkan oleh

: Dwi Prabantini, ANDI:

Yogyakarta

[3] Harsiti, Saefudin, dan Vidila Rosalina, 2014. Prototype Sistem Pendukung Keputusan Penyeleksian Atlet Berprestasi Dengan Menggunakan Metode Analytical Hierarchy Process (AHP), Prosiding SNaPP2014 Sains, Teknologi, dan Kesehatan ISSN 2089-3582 | EISSN 23032480

[4] Hendharto, H., 2008, Analytic Network Process (ANP) Method for Multi Purpose Research, http://www.portalhr.com/, diakses 08 November 2008 (15:30), (diakses: 29 Oktober 2016)

[5] Khoiruddin, A.A dan Maulana, R.A. 2014.Sistem Pendukung Keputusan Seleksi Pemain Futsal (Studi Kasus Ukm Futsal FTIUII), Proceeding from JBPTITBPP / 2014•03•14 07:52:57, Proceeding from JBPTITBPP / 2014•03•14 07:52:57

[6] Nurseta, M. Y., 2014. Sistem Pendukung Keputusan Pemilihan Starting Eleven Dalam Cabang 
Olahraga Sepakbola Menggunakan AHP, Skripsi, Program Studi Teknik Informatika, Universitas Islam Negeri Sunan Kalijaga, Yogyakarta

[7] rifanalfaizin, 2015. Artikel Olahraga Futsal,

http://rifanalfaizin.mhs.narotama.ac .id/2015/10/28/artikel-olahragafutsal/,

[8] Permana, Agus Aan Jiwa. 2016. Peran Sistem Pendukung Keputusan Dalam Purchasing Untuk Decision Maker, Jurnal New Media Vol. 7 No. 1 Maret 2016

[9] Saaty, T. L., 1999, Fundamentals of The Analytic Network Process, ISAHP 1999, Kobe-Japan, 12 - 14 Augustus 1999

[10]Setyawan,Aji dan Sutariyani.2013. Sistem Pendukung Keputusan Seleksi Calon Atlit Bulutangkis Berbakat PB. Djarum Kudus, Jurnal Ilmiah Go Infotech, Volume 19 No. 1, Juni 2013 ISSN : 1693$590 x$

[11] Tondo, Kusumo (2014) Sistem Pendukung Keputusan Seleksi Atlet Basket Pada Pplpd Jateng. Skripsi, Fakultas Ilmu Komputer.Universitas Dian Nuswantoro

[12] Utomo, S. P. K., dan Kurniawan, Praditya. 2016. Sistem Penunjang Keputusan Dalam Pemilihan Pemain Untuk Posisi Tertentu Pada Sepakbola, Seminar Nasional Teknologi Informasi dan Multimedia 2016 STMIK AMIKOM Yogyakarta, 6-7 Februari 2016, ISSN : 2302-3805, (diakses: 29 Oktober 2016)

[13] Wicaksono, Windi. 2016, Klub Sepak Bola Ini Cari Pemain Baru Lewat Media Sosial, http://bola.liputan6.com/read/ 2429674/klub-sepak-bola-inicari-pemain-baru-lewatmedia-sosial, (diakses: 29 Oktober 2016) 